\title{
Hospital-acquired infections due to multidrug-resistant organisms in Hungary, 2005-2010
}

S Caini (saverio.caini@gmail.com)1,2, A Hajdu¹ ${ }^{1}$ A Kurcz ${ }^{1}, K_{\text {Böröcz }}$

1. National Center for Epidemiology (NCE), Budapest, Hungary

2. European Programme for Intervention Epidemiology Training (EPIET), European Centre for Disease Prevention and Control (ECDC), Stockholm, Sweden

Citation style for this article:

Caini S, Hajdu A, Kurcz A, Böröcz K. Hospital-acquired infections due to multidrug-resistant organisms in Hungary, 2005-2010. Euro Surveill. $2013 ; 18$ (2):pii=20352. Available online: http://www.eurosurveillance.org/ViewArticle.aspx?Articleld=20352

Article submitted on 18 March 2012 / published on 10 January 2013

Healthcare-associated infections caused by multidrugresistant organisms are associated with prolonged medical care, worse outcome and costly therapies. In Hungary, hospital-acquired infections (HAIs) due to epidemiologically important multidrug-resistant organisms are notifiable by law since 2004. Overall, 6,845 case-patients $(59.8 \%$ men; median age: 65 years) were notified in Hungary from 2005 to 2010. One third of case-patients died in hospital. The overall incidence of infections increased from 5.4 in 2005 to 14.7 per 100,000 patient-days in 2010. Meticillinresistant Staphylococcus aureus (MRSA) was the most frequently reported pathogen $(52.2 \%)$, but while its incidence seemed to stabilise after 2007, notifications of multidrug-resistant Gram-negative organisms have significantly increased from 2005 to 2010. Surgical wound and bloodstream were the most frequently reported sites of infection. Although MRSA incidence has seemingly reached a plateau in recent years, actions aiming at reducing the burden of HAls with special focus on Gram-negative multidrug-resistant organisms are needed in Hungary. Continuing promotion of antimicrobial stewardship, infection control methodologies, reinforced $\mathrm{HAl}$ surveillance among healthcare and infection control practitioners, and engagement of stakeholders, hospital managers and public health authorities to facilitate the implementation of existing guidelines and protocols are essential.

\section{Introduction}

Healthcare-associated infections are infections arising from any aspect of healthcare management, most commonly during hospitalisation in acute care facilities (hospital-acquired infections, HAl) where the patient receives treatment for another medical or surgical condition. These infections are a significant cause of morbidity and mortality worldwide, primarily among immunocompromised and elderly people, especially if the causative organism has developed resistance to a number of antimicrobial agents. Patients infected with multidrug-resistant organisms usually have a significantly longer hospital stay, are more likely to be in need of intensive care, costly therapies and treatments, and have a worse prognosis [1]. While the burden of HAls due to multidrug-resistant organisms may vary widely according to geographical region, healthcare setting, type of pathogen and antimicrobial substance, its relevance to patient safety and public health continues to increase both nationally and internationally. Therefore surveillance of HAls caused by multidrug-resistant organisms, epidemiological, microbiological or both, has been established in most industrialised countries [2-6], and the need for a global approach has been recognised [7].

Data from the European Antimicrobial Resistance Surveillance Network (EARS-Net) are worrisome. The proportion of strains of major pathogens isolated from blood or cerebrospinal fluid (CSF) with resistance to important antimicrobial agents exceeds $10 \%$ or even $25 \%$ in several countries, with the highest figures seen in southern and eastern Europe $[8,9]$. Recently, national efforts in infection control in the European Union (EU) have led in some countries to a plateau or even a reversal of the trend of increasing resistance to antimicrobial agents, for example for meticillin-resistant Staphylococcus aureus (MRSA), penicillin- and/or macrolide-resistant Streptococcus pneumoniae and aminoglycoside-resistant Enterococci; however, increasing trends are still being observed for multidrug-resistant Escherichia coli and Klebsiella pneumoniae [9].

Carbapenems are currently considered as last-line antibiotics for the treatment of many infections caused by certain multidrug-resistant organisms. In particular, carbapenem resistance among Gram-negative microorganisms such as K. pneumoniae [9,10], Pseudomonas aeruginosa [9] and Acinetobacter baumannii [11] has recently increased in Europe.

In Hungary (population ca. 10 million), HAls due to epidemiologically important multidrug-resistant organisms are notifiable by law through the national surveillance system for nosocomial infections (Nemzeti Nosocomiális Surveillance Rendszer, NNSR) which was established in October 2004. Reporting is mandatory for all hospitals. We aimed at describing the patient population and infections due to multidrug-resistant 
organisms reported to the relevant surveillance module of the NNSR, and assessing the epidemiological trends during the period from 2005 to 2010 and the recent situation of reported HAls caused by multidrug. resistant organisms in Hungary.

\section{Methods}

Data source and reporting method

The NNSR, operated by the National Center for Epidemiology in Budapest, Hungary, is a national surveillance network and a database of nosocomial infections. Data on incident cases are collected, using surveillance methodology and $\mathrm{HAl}$ case definitions of the United States Centers for Disease Control and Prevention (US CDC) [12]. As of December 2010, the NNSR consisted of three compulsory modules (nosocomial outbreaks, HAl caused by multidrug-resistant

\section{TABLE 1}

Pathogens included in the module for hospital-acquired infections due to multidrug-resistant organisms of the national surveillance system for nosocomial infections in Hungary, 2005-10

\begin{tabular}{|c|c|}
\hline Microorganism & Antibiotic resistance \\
\hline $\begin{array}{l}\text { Staphylococcus } \\
\text { aureus (MRSA) }\end{array}$ & Meticillin/oxacillin \\
\hline Klebsiella sp. & $\begin{array}{l}\text { Third generation cephalosporins for ESBL- } \\
\text { production, imipenem and/or meropenem }\end{array}$ \\
\hline $\begin{array}{l}\text { Acinetobacter } \\
\text { baumannii }\end{array}$ & Imipenem and/or meropenem \\
\hline Escherichia coli & $\begin{array}{l}\text { Third generation cephalosporins for ESBL- } \\
\text { production, imipenem and/or meropenem }\end{array}$ \\
\hline $\begin{array}{l}\text { Pseudomonas } \\
\text { aeruginosa }\end{array}$ & $\begin{array}{l}\text { Sensitive to maximum two of the following } \\
\text { agents: piperacillin/tazobactam, ceftazidin, } \\
\text { cefepim, imipenem, meropenem, } \\
\text { ciprofloxacin, gentamicin, tobramycin, } \\
\text { amikacin, aztreonam }\end{array}$ \\
\hline Enterobacter sp. & $\begin{array}{l}\text { Third generation cephalosporins for ESBL- } \\
\text { production, imipenem and/or meropenem }\end{array}$ \\
\hline $\begin{array}{l}\text { Stenotrophomonas } \\
\text { maltophilia }\end{array}$ & Cotrimaxazol (sumetrolim) \\
\hline $\begin{array}{l}\text { Staphylococcus } \\
\text { aureus (VISA) }\end{array}$ & Intermediate sensitivity to vancomycin \\
\hline $\begin{array}{l}\text { Enterococcus sp. } \\
\text { (VRE) }\end{array}$ & Vancomycin \\
\hline
\end{tabular}

ESBL: extended spectrum beta-lactamase; MRSA: meticillinresistant Staphylococcus aureus; VISA: intermediate vancomycin-resistant $S$. aureus; VRE: vancomycin-resistant Enterococcus sp.

a VISA was added to the surveillance module in 2008.
organisms/Clostridium difficile, and nosocomial bloodstream infections), four voluntary modules (surgical site infections, intensive care unit- and perinatal intensive care unit-based surveillance, device-associated infections) and a disinfectant database [13]. Reporting of the compulsory elements is continuous.

The relevant surveillance module of the NNSR contains records from patients with HAl caused by a given multidrug-resistant organism at one or more anatomical sites, acquired during a given hospital stay. $\mathrm{HAl}$ is defined as a localised or systemic condition resulting from an adverse reaction to the presence of an infectious agent(s) or its toxin(s), with no evidence that the infection was present or incubating at the time of admission [12].

HAls caused by the following multidrug-resistant organisms were included in the period studied: meticillin-resistant S. aureus (MRSA), vancomycinresistant Enterococcus sp. (VRE), multidrug-resistant Enterobacter sp., multidrug-resistant Escherichia coli, multidrug-resistant Klebsiella sp., multidrug-resistant $A$. baumannii, multidrug-resistant $P$. aeruginosa, cotrimoxazole-resistant Stenotrophomonas maltophilia, and intermediate vancomycin-resistant $S$. aureus (VISA). The pathogens and key antibiotics to which resistance was monitored were selected through national expert consultations (Table 1). Throughout the period studied, resistance thresholds defined by the Clinical and Laboratory Standards Institute (CLSI) were used in laboratories in Hungary [14-19].

Variables required included information on patients' demographics (age, sex), lifestyle characteristics (smoking, alcohol consumption, drug abuse), medical history (concomitant diseases, recent surgeries), hospital stay (hospital ward, diagnosis upon admission, therapies or medical procedures applied as well as use of catheters before the recognition of $\mathrm{HAl}$ ), outcome at discharge (recovered, transferred to another hospital, deceased), and healthcare-associated infection caused by a multidrug-resistant organism (pathogen, type of infection, date of microbiological confirmation). Data on admission diagnosis, concomitant diseases and lifestyle characteristics were gathered from International Classification of Diseases (ICD-10) diagnosis codes documented in the medical records. Case-based data were entered in the internet-based surveillance tool by infection control (IC) nurses and, if available, approved by IC doctors when the patient affected was discharged from the hospital or dies. No post-discharge data are collected.

\section{Study design and study population}

We conducted a descriptive study including all notified cases of HAl due to multidrug-resistant organisms in Hungary until 2010. We defined a case-patient as a patient who was infected with one or more multidrugresistant organisms at one or more anatomical sites during a given hospital stay. Data from 2004 were 
discarded because the surveillance system was established and launched in that year, and the reported data are incomplete. Furthermore we excluded casepatients for whom date of admission, date of discharge or microbiological tests were not available.

\section{Descriptive and analytical methods}

We estimated the yearly coverage of the surveillance system by means of three indicators: proportion of all hospitals included in the system (hospitals notifying at least one multidrug-resistant organism/all hospitals in Hungary), proportion of hospitalisations (hospitalisation in the notifying hospitals/hospitalisations in all hospitals in Hungary), and proportion of patient-days (patient-days in the notifying hospitals/patient-days in all hospitals in Hungary).

We described HAI case-patients in terms of the following variables: sex, age at admission, lifestyle characteristics, underlying medical conditions, type of healthcare institution, hospital ward, medical procedures and devices applies, outcome, type of infection and type of multidrug-resistant organism.

We classified healthcare institutions into five categories: primary (typically city hospitals with essential medical specialties), secondary (typically county hospitals and large hospitals in the capital city with highly differentiated clinical functions), tertiary (central referral hospitals and university clinics with highly differentiated clinical functions, specialised staff and technical equipment), specialised hospitals (single clinical specialty, possibly with sub-specialties) as well as chronic care/rehabilitation hospitals.

Distributions of categorical variables between patient groups (e.g. case-patients with versus those without prior operation) were compared using the chi-square test. A p-value of 0.05 was considered to be statistically significant. For continuous variables, interquartile ranges (IQR) were calculated.

Annual incidence densities of reported HAls were calculated as: (number of HAls notified to NNSR during a given year) / (patient-days from all hospitals notifying at least one HAl that year) $x 100,000$. Incidence densities were calculated overall and stratified by multidrug-resistant organism. Denominator data were retrieved from official annual reports on hospital beds and patient turnover issued by the National Health Insurance Fund in Hungary [20].

The analyses were performed using Stata v10 (StataCorp LP).

\section{Results}

\section{Reporting hospitals}

The proportion of hospitals that reported at least one patient with $\mathrm{HAl}$ due to a multidrug-resistant organism to the NNSR gradually increased from $27.8 \%$ (50

\section{TABLE 2}

Selected characteristics ${ }^{\text {a }}$ of patients with reported hospitalacquired infection due to multidrug-resistant organism in Hungary, 2005-10 $(n=6,845)$

\begin{tabular}{|c|c|c|}
\hline Patient characteristics & Number & $\begin{array}{l}\text { Proportion of study } \\
\text { population (\%) }\end{array}$ \\
\hline \multicolumn{3}{|l|}{ Sex } \\
\hline Male case-patients & 4,095 & 59.8 \\
\hline Female case-patients & 2,750 & 40.2 \\
\hline \multicolumn{3}{|c|}{ Age group (age at admission) } \\
\hline $0-10$ years & 211 & 3.1 \\
\hline $11-20$ years & 93 & 1.4 \\
\hline $21-30$ years & 189 & 2.8 \\
\hline $31-40$ years & 291 & 4.2 \\
\hline $41-50$ years & 556 & 8.1 \\
\hline $51-60$ years & 1,315 & 19.2 \\
\hline $61-70$ years & 1,614 & 23.6 \\
\hline $71-80$ years & 1,715 & 25.1 \\
\hline $81-90$ years & 807 & 11.8 \\
\hline $91-100$ years & 54 & 0.8 \\
\hline \multicolumn{3}{|l|}{ Lifestyle characteristics } \\
\hline Smoking & 597 & 8.7 \\
\hline Alcohol abuse & 538 & 7.9 \\
\hline \multicolumn{3}{|l|}{ Concomitant diseases } \\
\hline Cardiovascular disease & 3,015 & 44.0 \\
\hline $\begin{array}{l}\text { Chronic respiratory } \\
\text { disease }\end{array}$ & 1,072 & $15 \cdot 7$ \\
\hline Cancer & 970 & 14.2 \\
\hline Chronic kidney disease & 545 & 8.0 \\
\hline
\end{tabular}

a Based on relevance and frequency.

of 180 ) in 2005 to $43.6 \%$ (75 of 172 ) in 2010. In 2005 , reporting hospitals received $64.0 \%$ of hospitalisations and accounted for $58.5 \%$ of patient-days in Hungary, while in 2010 the corresponding figures were $87.8 \%$ and $78.7 \%$.

\section{Patient population}

Overall, 8,673 case-patients were reported between 2004 and 2010. After applying exclusion criteria, 6,845 case-patients $(59.8 \%$ men; median age at admission: 65 years, range: $1-98$ years) were included in the analysis as study population (Table 2). The most frequently reported concomitant diseases were cardiovascular (44.0\%) and chronic respiratory diseases (15.7\%). The number of reported case-patients increased from 590 in 2005 to 1,807 in 2010. The median length of hospital stay was 25 days (IQR: 14-42 days) in the study population. The proportion of case-patients infected with more than one multidrug-resistant organism during the same hospital stay was around $18 \%$ each year; the median length of their hospital stay was 39 days 


\section{TABLE 3}

Characteristics of hospital stay of case-patients with reported hospital-acquired infection due to multidrugresistant organism in Hungary, 2005-10 $(n=6,845)$

\begin{tabular}{|l|c|c|}
\hline $\begin{array}{l}\text { Characteristics of } \\
\text { hospital stay }\end{array}$ & Number & $\begin{array}{r}\text { Proportion of study } \\
\text { population (\%) }\end{array}$ \\
\hline \begin{tabular}{l} 
Ward at admission \\
\hline Surgical ward
\end{tabular} & 2,523 & 36.9 \\
\hline Intensive care unit & 2,082 & 30.4 \\
\hline Medical ward & 1,754 & 25.6 \\
\hline Rehabilitation ward & 256 & 3.7 \\
\hline Obstetrics and gynaecology ward & 47 & 0.7 \\
\hline Paediatrics ward & 41 & 0.6 \\
\hline Psychiatry ward & 39 & 0.6 \\
\hline Other/mixed & 38 & 0.6 \\
\hline Missing & 65 & 1.0 \\
\hline Medical interventions and devices & & \\
\hline Prior surgical intervention & 3,762 & 55.0 \\
\hline Urinary catheter & 3,888 & 56.8 \\
\hline Peripheral catheter & 3,711 & 54.2 \\
\hline Central venous catheter & 2,706 & 39.5 \\
\hline Endotracheal tube & 2,029 & 29.6 \\
\hline Parenteral nutrition & 1,671 & 24.4 \\
\hline Tracheostomy & 1,007 & 14.7 \\
\hline Gastrostomy & 143 & 2.1 \\
\hline External ventricular drain & & \\
\hline & & \\
\hline
\end{tabular}

(IQR: 24-61 days). The median number of days elapsed between date of admission and date of first microbiological confirmation of an HAl due to a multidrugresistant organism was 12 (IQR: 6-21 days).

The number of case-patients notified by primary, secondary, tertiary, specialised and chronic care/rehabilitation hospitals was 1,163 (17.0\%), 3,099 (45.3\%), $2,433(35.5 \%), 104(1.5 \%)$ and $46(0.7 \%)$, respectively. Fourteen hospitals accounted for more than half $(3,560$ of 6,845 ) of all reported case-patients. Almost one third of all case-patients $(1,950$ of 6,845$)$ were reported from hospitals located in the capital city, Budapest.

In Table 3, data on hospital stay (ward at admission, medical procedures and devices applied) are reported. Among surgical specialties, the most frequently reported wards were general surgery (40.7\%), traumatology (24.7\%) and urology (11.5\%), and among medical specialties general internal medicine (46.8\%), haematology-oncology (12.1\%) and infectious diseases $(9.7 \%)$. Fifty-five per cent of case-patients underwent prior surgical intervention, most commonly gastrointestinal and liver surgery $(24.4 \%$, excluding transplantations), orthopedic surgery $(19.0 \%)$, neurosurgery (5.1\%) and head and neck surgery (4.6\%).
Case-patients with prior surgery had a lower prevalence of cardiovascular disease $(41 \%$ versus $47 \%$, p $<0.001)$, chronic respiratory disease $(11 \%$ versus $21 \%$, p $<0.001)$ and chronic kidney disease ( $5 \%$ versus $11 \%$, p<0.001) compared to those without. No difference was found in age and sex distribution between the two groups. Among case-patients who underwent prior surgery the most common types of HAl were $54.6 \%$ surgical site infection (SSI), 9.7\% bloodstream infection and 9.6\% urinary tract infection (UTI). The most frequent types of infection among those without prior surgery were bloodstream infection (21.9\%), UTI (17.2\%) and pneumonia (13.9\%).

Information on the outcome during the current hospital stay was available for 6,388 case-patients (93.3\%). Of them, 2,772 (43.4\%) recovered, 1,470 (23.0\%) were transferred to another hospital, and 2,146 (33.6\%) died. Patients infected with multidrug-resistant $P$. aeruginosa and $A$. baumannii had the highest casefatality $(43.8 \%$ and $40.2 \%$, respectively); case fatality for MRSA infection was $32.6 \%$. Patients infected with more than one multidrug-resistant organism had a case-fatality of $48.7 \%$. Among all deaths, according to the reports, $14.2 \%$ were related directly or indirectly to the HAI.

\section{Reported hospital-acquired infections}

Of the 6,845 case-patients, 5,482 (80.1\%) were infected with one multidrug-resistant organism at one anatomical site, $1,094(16.0 \%)$ with one multidrug-resistant organism at more than one anatomical site, 129 (1.9\%) with more than one multidrug-resistant organism at one anatomical site, and 140 (2.0\%) with more than one multidrug-resistant organism at more than one anatomical site. The overall number of individual HAls reported was 8,732 . The overall incidence of $\mathrm{HAl}$ due to multidrug-resistant organisms increased from 5.4 in 2005 to 14.7 per 100,000 patient-days in 2010 . The overall yearly incidence (per 100,000 patient-days) of HAI in primary, secondary, tertiary, specialised and chronic care/rehabilitation hospitals was 9.4, 9.1, 11.2, 7.5 and 3.2 , respectively.

MRSA was the most frequent single cause of HAI during the study period ( $n=4,477,52.2 \%$ ), but while MRSA numbers stabilised after 2007 (annual notifications were 471 in 2005, 826 in 2007 and 824 in 2010), notifications of all the other multidrug-resistant organisms kept increasing during 2005 to 2010 from 247 to 1,468 . As a result, MRSA represented $65.6 \%$ and $36.0 \%$ of all HAls in 2005 and 2010, respectively. Incidence rates of reported HAls by type of multidrug-resistant organism (excluding vancomycin-resistant Enterococcus sp., cotrimoxazole-resistant S. maltophilia and intermediate vancomycin-resistant $S$. aureus, which never exceeded an annual incidence rate of 0.1 per 100,000 patientdays in any given year) are shown in Figure 1.

SSI and bloodstream infection were the two most frequently reported sites during the whole study period; 
Annual incidence rates of reported hospital-acquired infections due to multidrug-resistant organisms in Hungary, 2005-10 $(\mathrm{n}=8,732)$

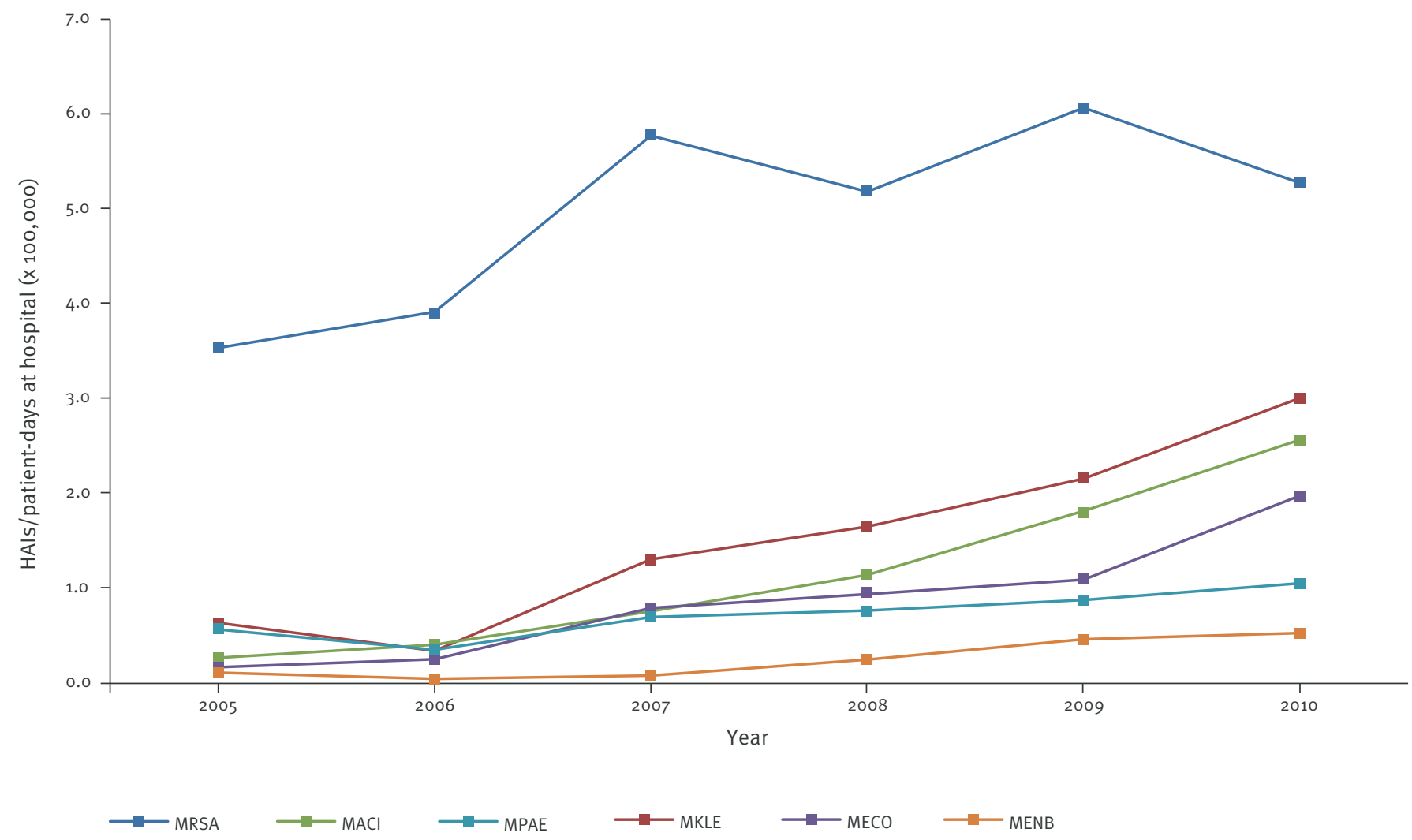

HAI: healthcare-associated infection; MACl: multidrug-resistant Acinetobacter baumannii; MECO: multidrug-resistant Escherichia coli; MENB: multidrug-resistant Enterobacter sp.; MKLE: multidrug-resistant Klebsiella sp; MPAE: multidrug-resistant Pseudomonas aeruginosa; MRSA: methicillin-resistant Staphylococcus aureus.

yet their proportion among all reported HAls due to multidrug-resistant organisms decreased from $31.9 \%$ to $25.1 \%$ and from $25.9 \%$ to $21.7 \%$, respectively, from 2005 to 2010 . The proportion of reported urinary tract infections increased from $7.7 \%$ in 2005 to $19.3 \%$ in 2010.

Considerable differences were found in the distribution of the type of infections by multidrug-resistant organism (Figure 2). MRSA was the most frequently reported multidrug-resistant organism for all sites of infection in 2010 except for urinary tract and lower respiratory tract (Figure 3). However, the proportion of MRSA as cause of HAl decreased at each site of infection between 2005 and 2010, while an increase was seen in the proportion of multidrug-resistant $A$. baumannii (at all infection sites, except for urinary tract), E. coli (particularly bloodstream and urinary tract infections) and Klebsiella sp. (particularly surgical site and soft tissue infections).

\section{Discussion}

The coverage of Hungarian hospitals by the NNSR has constantly grown over the years. Although less than half of all hospitals notified at least one infection due to multidrug-resistant organisms in 2010, these healthcare institutions accounted for the vast majority of hospitalisations and patient-days in the country during that year. Efforts to further expand the coverage of the surveillance system should focus on those hospitals not currently reporting: mainly smaller facilities and chronic care hospitals.

The proportion of reports sent by primary, specialised and chronic care/rehabilitation hospitals was lower than their relative proportion of overall number of acute and chronic beds in Hungary. The opposite was observed for tertiary-level hospitals, while no difference was found for secondary-level hospitals. Varying compliance with reporting, case-mix of patients and presence or absence of high-risk specialties are the most plausible explanations for these differences. 


\section{FIGURE 2}

Most frequent types of reported hospital-acquired infections due to multidrug-resistant organisms in Hungary in $2010(\mathrm{n}=2,252)$

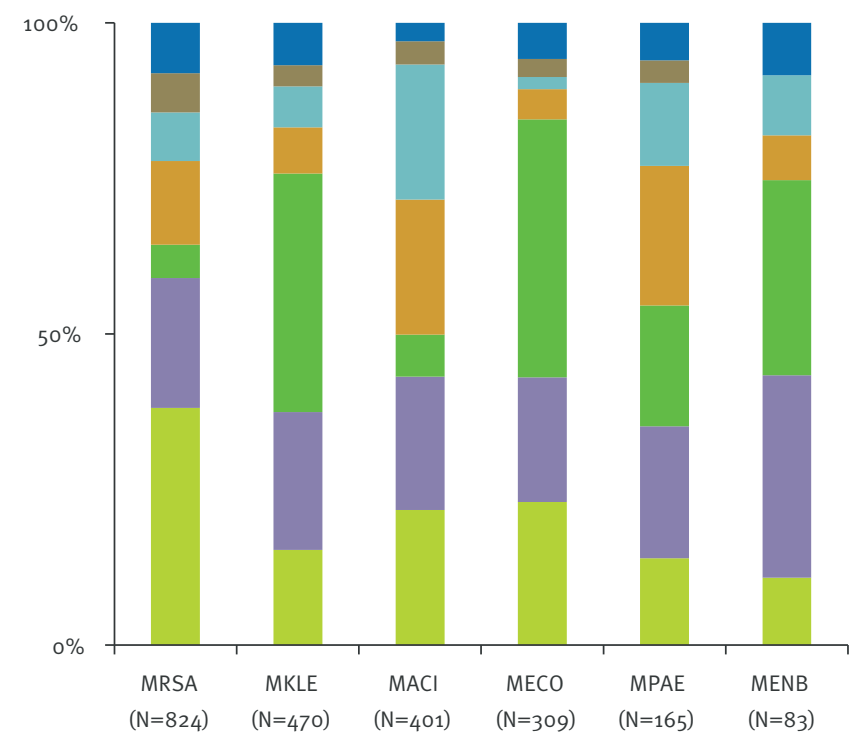

Other anatomical sites

Urinary tract infection

Skin and soft tissues infection

Bloodstream infection

Lower respiratory tract infection

Surgical site infection

Pneumonia

MACI: multidrug-resistant Acinetobacter baumannii; MECO: multidrug-resistant Escherichia coli; MENB: multidrug-resistant Enterobacter sp.; MKLE: multidrug-resistant Klebsiella sp; MPAE: multidrug-resistant Pseudomonas aeruginosa; MRSA: meticillinresistant Staphylococcus aureus.

Surgical departments were the most frequent hospital wards concerned, and further investigations are needed to disentangle the possible impact of parallel surveillance activities linked to the SSI module of the NNSR, and specific issues in perioperative care. ICUs were the second in line which is likely due to the presence of high-risk patients, better patient monitoring, including higher frequency of sampling and more timely microbiological diagnosis. Similarly, an influence of the dedicated ICU surveillance module cannot be excluded. A more in-depth description should assess differences by region, individual hospitals and ward types.

The population of case-patients affected by HAl due to multidrug-resistant organisms was characterised by old age at admission, a high prevalence of comorbidities, and a large proportion of prior surgical interventions and indwelling medical devices. All these are known risk factors for developing an $\mathrm{HAl}$, either by impairing the immune system or by facilitating the entry of a multidrug-resistant organism through a medical procedure [21].

One third of the case-patients died during their hospitalisation. This figure is probably biased downwards considering that no information on final outcome is available for patients who were transferred to another hospital. According to the notification data, $14.2 \%$ of deaths could directly be ascribed to the HAI; however, no definition of HAl-related death exists in the NNSR to which reporting personnel must adhere.

MRSA was the most frequent cause of HAl at most anatomical sites except for UTIs and lower respiratory tract infections (LRTIs), exceeding 50\% of all reported HAls at surgical site as well as skin and soft tissues. Multidrug-resistant $A$. baumannii was the most frequent cause of LRTI, probably linked to ventilation and oral care practices. Extended-spectrum beta-lactamase (ESBL)-producing bacteria are increasingly causing UTI in inpatients and outpatients worldwide [22]. Also in Hungary, the proportion of reported UTIs due to multidrug-resistant organisms more than doubled over the study period; multidrug-resistant $K$. pneumoniae and multidrug-resistant $E$. coli accounted for approximately $70 \%$ of reports. This is most likely due to both the increased occurrence, spread and microbiological diagnoses of these pathogens. Improved awareness can also be a contributing factor since the issue has been extensively discussed at infection control meetings in Hungary since 2009, and a recommendation on the prevention of catheter-associated urinary tract infections was published in the same year.

The overall incidence of reported HAls due to multidrug-resistant organisms in Hungary has shown a significant increase in recent years, but different tendencies are seen for Gram-positive and Gram-negative pathogens. Concerning Gram-positive pathogens, the incidence of MRSA infections has lately reached a plateau in some European countries [23] and in the United States [24]. Similarly in Hungary, MRSA incidence seemed to have stabilised around six infections per 100,000 patient-days over the last four years of the study period, when the reporting system was already established in major hospitals. In other words, at the beginning of surveillance, the continuously improving reporting of MRSA infections could have been the reason for the increase in observed incidence. After this initial period, we assume that the observed incidence approached the true incidence which has remained stable since then. Nonetheless, this figure is lower than those reported by most other European [3,25-27] and non-European countries $[23,28,29]$. For instance, the incidence of hospital-onset MRSA in Germany was 23 per 100,000 patient-days in 2009 , approximately four times higher than the Hungarian result [3]. In Canada [28], the figure was 34.3 per 100,000 patient-days in 2007, around six times higher than in Hungary. The 
Most frequently reported multidrug-resistant organisms by type of hospital-acquired infection in Hungary in 2010 $(\mathrm{n}=2,143)$

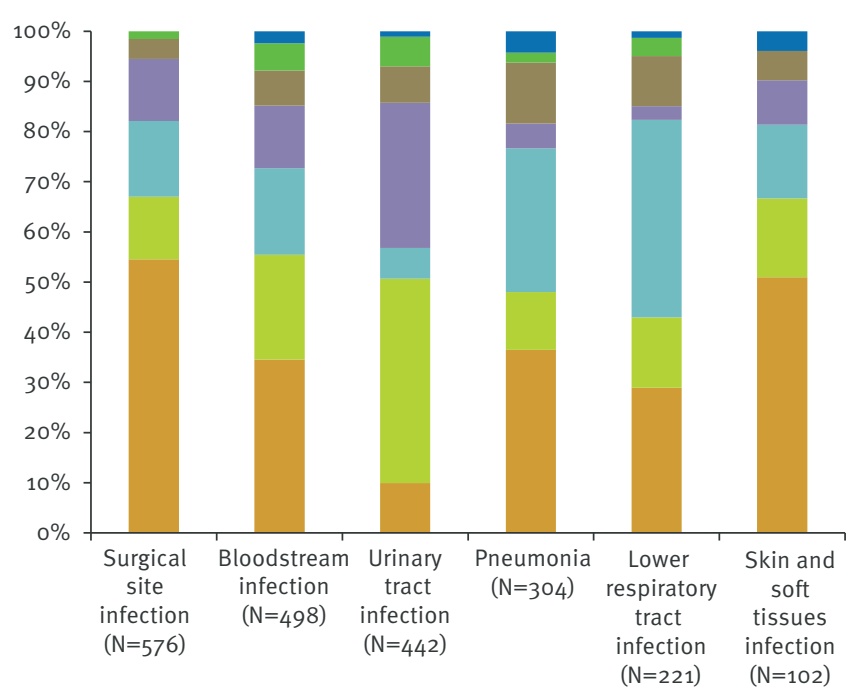

Other MDRO MPAE
MENB MECO MCI

MACI: multidrug-resistant Acinetobacter baumannii; MECO: multidrug-resistant Escherichia coli; MENB: multidrug-resistant Enterobacter sp.; MKLE: multidrug-resistant Klebsiella sp; MPAE: multidrug-resistant Pseudomonas aeruginosa; MRSA: meticillinresistant Staphylococcus aureus.

number of reported cases per 100,000 population in 2010 was 8.8 in Norway [27] and 16.8 and Sweden [26], to be compared with a value of 8.24 in Hungary. How much this is due to underreporting or true differences in incidence is hard to establish; differences in the frequency of microbiological sampling, availability of microbiological services, structure of surveillance systems and general compliance with reporting may also play an important role.

Prevention and control of infections caused by meticillin/oxacillin resistant $S$. aureus has been facilitated by a national guidance available in Hungary since 2001. Due to improved knowledge over time, not only infection control practitioners, but also healthcare workers have become familiar with necessary actions to be taken in case of MRSA in hospitals. Nonetheless it serves as a warning that the proportion of $S$. aureus resistant to meticillin isolated from blood is currently around $30 \%$ in Hungary, with a significant increase seen between 2007 and 2010 [9].

In contrast to the incidence pattern of Grampositive MRSA, the incidence of infections caused by multidrug-resistant Gram-negative organisms has continuously increased since the establishment of NNSR. The magnitude of this increase is striking (the ratio of incidences in 2010 versus 2005 is 11 for multidrugresistant E. coli, 9 for multidrug-resistant $A$. baumannii, 6 for co-trimoxazole-resistant S. maltophilia, 5 for multidrug-resistant Enterobacter sp. and 5 for multidrug-resistant Klebsiella sp.), similarly to what has been observed in the EU [9] and also countries outside the EU [30-33] in the same time period. Therefore there appears to be a true increase in their incidence in Hungary, whereas the impact of improved reporting due to better awareness of the problem may obviously play a role, too. Recent surveillance results show that incidences of most multidrug-resistant organisms in 2011 are comparable to their respective values observed in 2010, except for multidrug-resistant $A$. baumannii, whose incidence further increased.

While extensive or inappropriate antimicrobial use may be the key factor in the striking emergence of multidrug-resistant Gram-negative organisms, their current successful spread, compared to MRSA, could also be attributed to particular microbiological characteristics (e.g. a successful decolonisation strategy is not available) and more efficient survival strategies through dissemination of acquired mechanisms of antibiotic resistance. Interestingly, Hungary is in the lower third of European countries regarding the quantity of outpatient antimicrobial consumption and had the lowest hospital use of antimicrobials for systemic use in 2009, nevertheless quality indicators of antibiotic use suggest issues need to be addressed both in ambulatory and hospital care [34-36]. We hypothesise that limited collecting of appropriate and early microbiological samples before initiating empiric antibiotic therapy, and therefore limited streamlining of antibiotic treatment based on culture results, may be the most relevant problem areas in practice.

A comprehensive evaluation of the National Nosocomial Surveillance System is planned in 2013 to assess its impact on the prevention and control of HAI in Hungary. At national level, surveillance results formed the basis for a decree issued by the Ministry of Health in 2009 (extended in its scope in 2012) on the prevention and control of HAl, surveillance of antimicrobial consumption and professional minimum requirements [37]. Governmental bodies and institutions with public health function were involved in the organisation of national campaigns linked to the European Antibiotic Awareness Day targeting both professionals and the public. National recommendations have already been issued for MRSA, VISA, ESBL-producing Gramnegative pathogens, VRE, and carbapenemase-producing Enterobacteriaceae [38-44]. However, partially as a reaction to the current epidemiological trends, a new comprehensive recommendation on prevention of infections caused by Gram-positive and emerging Gram-negative multidrug-resistant pathogens is being developed. 
While national actions are essential, prevention efforts will have the desired effect only if existing guidelines and protocols are effectively and efficiently implemented in hospitals and followed in routine practice, tailored to the situation described by local surveillance results. Measures implemented at hospital level over the years also have to be reviewed and evaluated. Additional financial resources are needed for hospitals to be able to meet all legal requirements and provide continuous training for their personnel. Promotion of microbiological diagnosis would also be highly relevant. A number of obstacles should be addressed, for example healthcare reimbursement through diagnosisrelated groups without separate budget for diagnostics and treatment, which may currently act as a disincentive to taking samples for microbiological tests.

In summary, our results highlight that, in addition to the efforts made until now, further actions are needed in Hungary, both at locally and nationally to reduce the burden of HAls due to multidrug-resistant organisms.

\section{Acknowledgments}

We would like to thank Dr. Ákos Tóth at the National Center for Epidemiology, Dr. Carl Suetens and Dr. Biagio Pedalino at the European Centre for Disease Prevention and Control (ECDC) for their valuable comments to the manuscript.

\section{References}

1. Ben-David D, Novikov I, Mermel LA. Are there differences in hospital cost between patients with nosocomial methicillin resistant Staphylococcus aureus bloodstream infection and those with methicillin-susceptible Staphylococcus aureus bloodstream infection? Infect Control Hosp Epidemiol. 2009;30(5):453-60

2. Centers for Disease Control and Prevention (CDC). National Healthcare Safety Network (NHSN). Atlanta: CDC. [Accessed: 19 Dec 2012]. Available from: http://www.cdc.gov/nhsn/

3. Nationales Referenzzentrum für Surveillance von nosokomialen Infektionen (NRZ) [German National Reference Center for the Surveillance of Nosocomial Infections]. MRSA-KISS Reference Data, 2009. Berlin: NRZ. [Accessed: 19 Dec 2012]. Available from: http://www.nrz-hygiene.de/en/surveillance/ hospital-infection-surveillance-system/mrsa-kiss/

4. Geffers C, Gastmeier P. Nosocomial infections and multidrug. resistant organisms in Germany: epidemiological data from KISS (the Hospital Infection Surveillance System). Dtsch Arztebl Int. 2011;108(6):87-93.

5. Centres de Coordination de la Lutte contre les Infections Nosocomiales (CCLIN) [Infection Control Coordinating Centres]. Homepage. Nancy: CCLIN. [Accessed: 19 Dec 2012]. French. Available from : http://www.cclin-france.fr/

6. Carlet J, Astagneau P, Brun-Buisson C, Coignard B, Salomon $V$, Tran B, et al. French national program for prevention of healthcare associated infections and antimicrobial resistance, 1992-2008: positive trends, but perseverance needed. Infect Control Hosp Epidemiol. 2009;30(8):737-45.

7. Transatlantic Taskforce on Antimicrobial Resistance (TATFAR). Recommendations for future collaboration between the U.S. and EU. TATFAR; 2011. Available from: http://www.cdc.gov/ drugresistance/pdf/tatfar-report.pdf

8. European Centre for Disease Prevention and Control. Annual Epidemiological Report 2011. Reporting on 2009 surveillance data and 2010 epidemic intelligence data. Stockholm: ECDC; 2011. Available from: http://www.ecdc.europa.eu/en/ publications/Publications/Forms/ECDC_DispForm.aspx?ID $=767$

9. European Centre for Disease Prevention and Control (ECDC). Antimicrobial resistance surveillance in Europe 2010. Annual Report of the European Antimicrobial Resistance Surveillance Network (EARS-Net). Stockholm: ECDC; 2011. Available from: http://ecdc.europa.eu/en/publications/Publications/1111 SUR_AMR_data.pdf.pdf

10. Vatopoulos A. High rates of metallo-beta-lactamaseproducing Klebsiella pneumoniae in Greece--a review of the current evidence. Euro Surveill. 2008;13(4):pii=8023. Available from: http://www.eurosurveillance.org/ViewArticle. aspx?Articleld $=8023$

11. Durante-Mangoni E, Zarrilli R. Global spread of drug resistant Acinetobacter baumannii: molecular epidemiology and management of antimicrobial resistance. Future Microbiol. 2011; 6(4):407-22.

12. Horan TC, Andrus M, Dudeck MA. CDC/NHSN surveillance definition of health care-associated infection and criteria for specific types of infections in the acute care setting. Am J Infect Control. 2008;36(5):309-32.

13. Országos Epidemiológiai Központ [National Center for Epidemiology]. Tájékoztató a Nemzeti Nosocomialis Surveillance Rendszer (NNSR) és a Nemzeti Bakteriológiai Surveillance (NBS) 2010. évi eredményeiről [Annual Reports of the National Surveillance System for Nosocomial Infections (NNSR) and the National Bacteriological Surveillance System (NBS), 2010] Epinfo. 2011;6. supplement. Hungarian. Available from: http://www.oek.hu/oek.web?to=839,1890\&nid=964\&pi $\mathrm{d}=1$ \&lang=hun

14. Clinical and Laboratory Standards Institute (CLSI). Performance Standards for Antimicrobial Susceptibility Testing: Fifteenth Informational Supplement M100-S15. Wayne: CLSI; 2005.

15. Clinical and Laboratory Standards Institute (CLSI). Performance Standards for Antimicrobial Susceptibility Testing: Sixteenth Informational Supplement M100-S16. CLSI Wayne: CLSI; 2006

16. Clinical and Laboratory Standards Institute (CLSI). Performance Standards for Antimicrobial Susceptibility Testing: Seventeenth Informational Supplement M100-S17. Wayne: CLSI; 2007.

17. Clinical and Laboratory Standards Institute (CLSI). Performance Standards for Antimicrobial Susceptibility Testing: Eighteenth Informational Supplement M100-S18. Wayne: CLSI; 2008.

18. Clinical and Laboratory Standards Institute (CLSI). Performance Standards for Antimicrobial Susceptibility Testing: Nineteenth Informational Supplement M100-S19. Wayne: CLSI; 2009.

19. Clinical and Laboratory Standards Institute (CLSI). Performance Standards for Antimicrobial Susceptibility Testing: Twentieth Informational Supplement M100-S20. Wayne: CLSI; 2010. 
20. Országos Egészségbiztosítási Pénztár [National Health Insurance Fund Administration of Hungary]. Kórházi Ágyszámés Betegforgalmi Kimutatás. [Hospital beds and patient turnover account]. [Date of access: 19 Dec 2012] Hungarian. Available from http://www.gyogyinfok.hu/magyar/archiv.html

21. Puhto T, Ylipalosaari P, Ohtonen P, Syrjala H. Point prevalence and risk factors for healthcare-associated infections in primary healthcare wards. Infection. 2011;39(3):217-23.

22. Coque TM, Baquero F, Canton R. Increasing prevalence of ESBL-producing Enterobacteriaceae in Europe. Eurosurveill. 2008;13(47): pii=19044. Available from: http://www. eurosurveillance.org/ViewArticle.aspx?Articleld=19044

23. Pearson A, Chronias A, Murray M. Voluntary and mandatory surveillance for methicillin-resistant Staphylococcus aureus (MRSA) and methicillin-susceptible Staphylococcus aureus (MSSA) bacteraemia in England. J Antimicrob Chemother. 2009;64 Suppl 1:i11-7.

24. Kallen AJ, Mu Y, Bulens S, Reingold A, Petit S, Gershman K, et al. Health care-associated invasive MRSA infections, 20052008. JAMA. 2010;304(6):641-8.

25. Health Protection Agency (HPA). Quarterly epidemiological commentary: mandatory MRSA, MSSA and E. coli bacteraemia, and C.difficile infection data (up to July-September 2012). London: HPA; 13 Dec 2012. Available from: http://www.hpa. org.uk/webc/HPAwebFile/HPAweb_C/1284473407318

26. Smittskyddsinstitutet (SMI) [Swedish Institute for Communicable Disease Control]. Statistik för meticillinresistenta gula stafylokocker (MRSA). [Statistics for meticillin-resistant Staphylococcus aureus (MRSA)) Swedish. Available from: http://www.smittskyddsinstitutet.se/statistik/ meticillinresistenta-gula-stafylokocker-mrsa/

27. Elstrøm P, Kacelnik O, Bruun T, Iversen B, Hauge SH, Aavitsland P. Meticillin-resistant Staphylococcus aureus in Norway, a lowincidence country, 2006-2010. J Hosp Infect. 2012;80(1):36-40.

28. Simor AE, Gilbert NL, Gravel D, Mulvey MR, Bryce E, Loeb M, et al. Methicillin-resistant Staphylococcus aureus colonization or infection in Canada: National Surveillance and Changing Epidemiology, 1995-2007. Infect Control Hosp Epidemiol. 2010;31(4):348-56.

29. Lessa FC, Mu Y, Davies J, Murray M, Lillie M, Pearson A, et al. Comparison of incidence of bloodstream infection with methicillin-resistant Staphylococcus aureus between England and United States, 2006-2007. Clin Infect Dis. 2010;51(8):925-8.

30. Lautenbach E, Synnestvedt M, Weiner MG, Bilker WB, Vo L, Schein J, et al. Epidemiology and impact of imipenem resistance in Acinetobacter baumannii. Infect Control Hosp Epidemiol. 2009;30(12):1186-92.

31. Lautenbach E, Synnestvedt M, Weiner MG, Bilker WB, Vo $L$, Schein J, et al. Imipenem resistance in Pseudomonas aeruginosa: emergence, epidemiology, and impact on clinical and economic outcomes. Infect Control Hosp Epidemiol. 2010;31(1):47-53.

32. Ramsey AM, Zilberberg MD. Secular trends of hospitalization with vancomycin-resistant enterococcus infection in the United States, 2000-2006. Infect Control Hosp Epidemiol. 2009;30(2):184-6.

33. Lee K, Kim MN, Kim JS, Hong HL, Kang JO, Shin JH, et al. Further increases in carbapenem-, amikacin-, and fluoroquinoloneresistant isolates of Acinetobacter spp. and P. aeruginosa in Korea: KONSAR study 2009. Yonsei Med J. 2011;52(5):793-802.

34. European Surveillance of Antimicrobial Consumption (ESAC). ESAC Yearbook 2009. Antwerp: ESAC. [Accessed: 19 Dec 2012]. ISBN: 9789057283307 . Available from: http://www.ecdc. europa.eu/en/activities/surveillance/ESAC-Net/publications/ Pages/documents.aspx

35. Adriaenssens N, Coenen S, Versporten A, Muller A, Vankerckhoven V, Goossens H; ESAC Project Group. European Surveillance of Antimicrobial Consumption (ESAC): quality appraisal of antibiotic use in Europe. J Antimicrob Chemother. 2011;66Suppl 6:vi71-77. doi: 10.1093/jac/dkr459.

36. Benko R, Matuz M, Peto Z, Bogár L, Viola R, Doró P, et al. Variations and determinants of antibiotic consumption in Hungarian adult intensive care units. Pharmacoepidemiol Drug Saf. 2012;21(1):104-9.

37. 20/2009. (VI. 18.) EüM rendelet az egészségügyi ellátással összefüggő fertőzések megelőzéséről, e tevékenységek szakmai minimumfeltételeiról és felügyeletéről. [Decree of the Ministry of Health on prevention of healthcare-associated infections, related professional minimum requirements and control activities]. [Accessed: 18 Dec 2012]. Hungarian. Available from: http://www.complex.hu/jr/gen/hjegy_doc. cgi?docid $=$ A0900020.EUM

38. Országos Epidemiológiai Központ [National Center for Epidemiology]. Módszertani levél a Methicillin/Oxacillin Rezisztens Staphylococcus Aureus (MRSA) fertőzések megelőzésére. [Methodological letter on the prevention of infections caused by meticillin/oxacillin-resistant Staphylococcus aureus (MRSA)].Epinfo. 2001;8(5. különszám). Hungarian. Available from: http://www.oek.hu/oek.web?nid=4 44 \& pid $=2 \&$ to $=16$ \&lang $=$ hun

39. Országos Epidemiológiai Központ [National Center for Epidemiology]. A széles spektrumú béta-laktamázokat termelő Gram-negatív baktériumok jelentősége és az általuk okozott nosocomialis járványok leküzdése. [The importance of extended-spectrum beta-lactamase producing Gram-negative bacteria and control of such nosocomial outbreaks]. Epinfo. 2002;30:349-52. Hungarian. Available from: http://www.oek. hu/oek.web?nid=1080\&pid=1

40. Országos Epidemiológiai Központ [National Center for Epidemiology]. Vancomycin-rezisztens Enterococcus (VRE) fertőzések megelőzése az egészségügyi intézményekben. [Prevention of infections caused by vancomycin-resistant enterococci (VRE) in healthcare facilities]. Epinfo. 2004;42:52226. Hungarian. Available from: http://www.oek.hu/oek. web? nid=1080\&pid=1

41. Országos Epidemiológiai Központ [National Center for Epidemiology]. A multirezisztens kórokozók felügyelete az egészségügyi intézményekben. [Control of multidrug-resistant pathogens in healthcare facilities]. Epinfo, 2007;10-11:8998. Hungarian. Available from: http://www.oek.hu/oek. web?nid=1080\&pid=1

42. Országos Epidemiológiai Központ [National Center for Epidemiology]. Ajánlás a hVISA/VISA azonosítása esetén szükséges teendőkről és a kórokozó terjedésének megelőzését célzó infekciókontroll intézkedésekről. [Recommendations on actions required upon the detection of hVISA/VISA and on infection control measures to prevent its spread]. Epinfo. 2008;15:173-6. Hungarian. Available from: http://www.oek.hu/ oek.web?to=1493,1494,1495,1480\&nid=41\&pid=8\&lang=hun

43. Országos Epidemiológiai Központ [National Center for Epidemiology]. A S. aureus vancomycinnel szembeni rezisztenciája. [Vancomycin resistance of S. aureus]. Epinfo. 2008;15:177-9. Hungarian. Available from: http://www.oek.hu/ oek.web?to=1493,1494,1495,1480\&nid=41\&pid=8\&lang=hun

44. Országos Epidemiológiai Központ [National Center for Epidemiology]. Ajánlás a karbapenemáz-termeló Enterobacteriaceae törzsek azonosítására és terjedésük megelózésére az egészségügyi intézményekben. [Recommendation on identification of carbapenemaseproducing enterobacteriaceae strains and prevention of their spread in healthcare facilities]. Epinfo. 2011;47:541-50. Hungarian. Available from: http://www.oek.hu/oek.web?to=83 9,1866\&nid=41\&pid=11\&lang=hun 